\title{
Bernhard Sterchi, Fortuna in Burgund Die theoretische Debatte im burgundischen Schriftgut und ihre Applikation bei Olivier de la Marche
}

\section{Antonella Conti}

\section{(2) OpenEdition}

\section{Journals}

Édition électronique

URL : http://journals.openedition.org/studifrancesi/35777

DOI : 10.4000/studifrancesi.35777

ISSN : 2421-5856

Éditeur

Rosenberg \& Sellier

\section{Édition imprimée}

Date de publication : 1 juillet 2005

Pagination : 138

ISSN : 0039-2944

\section{Référence électronique}

Antonella Conti, «Bernhard Sterchi, Fortuna in Burgund Die theoretische Debatte im burgundischen Schriftgut und ihre Applikation bei Olivier de la Marche », Studi Francesi [En ligne], 145 (XLIX | I) | 2005, mis en ligne le 30 novembre 2015, consulté le 20 avril 2021. URL : http://journals.openedition.org/ studifrancesi/35777 ; DOI : https://doi.org/10.4000/studifrancesi.35777

Ce document a été généré automatiquement le 20 avril 2021.

\section{cc) $(9)$}

Studi Francesi è distribuita con Licenza Creative Commons Attribuzione - Non commerciale - Non opere derivate 4.0 Internazionale. 


\title{
Bernhard Sterchi, Fortuna in Burgund Die theoretische Debatte im burgundischen Schriftgut und ihre Applikation bei Olivier de la Marche
}

\author{
Antonella Conti
}

\section{RÉFÉRENCE}

BERNHARD STERCHI, Fortuna in Burgund Die theoretische Debatte im burgundischen Schriftgut und ihre Applikation bei Olivier de la Marche, in Publication du Centre Européen d'Etudes Bourguignonnes (XIVe-XVIe s.) N43, 2003, Rencontres de Chalon-sur-Saône (26 au 29 septembre 2002) «Autour d'Olivier de la Marche» pp. 213-240.

Cette contribution a pour objet une notion très répandue à la cour de Bourgogne, à savoir l'influence que Fortune exerce tout spécialement sur l'existence des nobles. Après avoir rappelé la double interprétation de Fortune que la tradition philosophique avait léguée aux auteurs bourguignons, l'A. considère rapidement la manière dont Michault Taillevent, Charles Soillot, Jean et Hugues de Lannoy, Philippe de Croy et Georges Chastellain l'ont reçue et élaborée. Suit une analyse plus détaillée du Débat de Cuidier et de Fortune, qu'Olivier de la Marche a écrit sous l'impression de la chute de Charles le Téméraire, et des cas de morts exemplaires évoqués dans ses Mémoires: le meurtre de Jean sans Peur, la mort sur le champ de bataille de Pierre du Portugal et celle de Corneilles de Bourgogne lors de la révolte des Gantois, la fin - indigne d'un chevalier - de Jacques de Lalaing, la mort tragique de Charles le Téméraire. 